\title{
ХОЛОКОСТ В ОККУПИРОВАННЫХ РЕГИОНАХ СССР: ПРОБЛЕМА ПЕРИОДИЗАЦИИ И РЕГИОНАЛЬНЫХ ОСОБЕННОСТЕЙ
}

В статье критически рассматриваются и анализируются имеющиеся варианты периодизации Холокоста в бывшем СССР, предложенные израильским историком и исследователем Холокоста Иихаком Арадом и российским историком Ильей Альтманом. Как Арад, так и Альтман в основу периодизации кладут количественные изменения и внешние по отношению к Холокосту факторы, в то время как, по мнению автора статьи, научная периодизация должна основываться на качественных изменениях и внутренней логике развития исследуемого явления (в нашем случае - Холокоста). Исходя из этих принципов, автор приходит к выводу, что в Холокосте в СССР можно выделить только два этапа. Первый этап - с 22 июня 1941 г. до перехода к поголовному истреблению евреев и (второй этап) - с этого момента до полного освобождения советской территории.

На основе изучения соответствующей научной литературы, немеиких и советских документов (донесения немецких карательных органов, акты ЧГК) автор констатирует, что в разных оккупированных регионах СССР переход $к$ поголовному истреблению евреев произошел не одномоментно, а в разное время - в Латвии и в Белоруссии (Белостокская область) уже в начале июля 1941 г., в Литве в середине августа 1941 г., в Украине в третьей декаде августа 1941 г. По мнению автора, в основе этой разномоментности лежал человеческий фактор, а сам факт начала поголовного истребления евреев уже в начале июля 1941 г. говорит о том, что принципиальное решение об уничтожсении советских евреев как евреев большевистских (так называемый «приказ фюрера», т.е. Гитлера) было принято, скорее всего, до нападения Германии на СССР. В статье приводятся послевоенные показания ряда бывших «фюреров» команд СД о том, что о «приказе фюрера» им было объявлено еще до начала «кампании против России».

Ключевые слова: Холокост в СССР, периодизация Холокоста, оккупированная территория, истребление евреев, расстрелы. 


\section{Введение}

Проблема периодизации Холокоста в оккупированных регионах $\mathrm{CCCP}^{\prime}$ является одной из наименее изученных: специальных публикаций на эту тему не существует, хотя имеются попытки периодизации в общих работах по Холокосту в СССР. Между тем периодизация истории Холокоста является важной методологической проблемой: ее решение способствует реализации исследований, связанных с региональными особенностями Холокоста.

Периодизация характеризуется как методологический инструмент, с помощью которого чисто механическую сумму событий, фактов, явлений можно упорядочить, свести в определенную систему. А наличие системы, применение системного подхода является, как известно, одним из основных признаков науки. Однако эту свою функцию периодизация выполняет только в том случае, если она является научной. Существует два вида научной периодизации - формальная (периодизация по основному существенному признаку) и диалектическая (периодизация по основному внутреннему противоречию, характерному для данного явления, в нашем случае - для Холокоста). Ниже мы рассмотрим имеющиеся варианты формальной периодизации, покажем, почему они являются, по нашему мнению, некорректными, и предложим свой вариант периодизации Холокоста в СССР и вытекающие из него региональные особенности Холокоста. Поскольку наиболее типичными, на наш взгляд, являются варианты, предложенные Ицхаком Арадом и Ильей Альтманом, для анализа предлагаются эти периодизации.

\section{Периодизация Холокоста в СССР И. Арада и ее критика}

Одну из первых попыток периодизации Холокоста мы находим у известного израильского исследователя И. Арада (Yitzhak Arad), который выделил три периода в истреблении евреев на оккупированных территориях СССР: с 22 июня 1941 г. до зимы 1941-1942 гг.,

${ }_{1}^{1}$ Под «СССР» автор имеет в виду СССР в границах на середину 1941 г. Всех евреев на этой территории (и вообще евреев Восточной Европы) нацисты считали «большевистскими» и «коммунистическими», независимо от того, когда эти территории вошли в состав СССР, степени советизации и ассимиляции евреев на присоединенных в 1939-1940 гг. территориях, и что многие евреи, особенно Прибалтики и бывших польских и румынских территорий, были настроены антикоммунистически.

${ }^{2}$ Основным существенным признаком для формальной периодизации Холокоста является такой признак, который отличает Холокост как вид геноцида от других видов геноцида. Таким признаком и одновременно сутью Холокоста является тотальное истребление евреев нацистами только потому, что они являются евреями. когда было уничтожено большинство евреев, проживавших в Литве, Латвии, Эстонии, Молдавии (Бессарабия и Северная Буковина), и почти все евреи Восточной Белоруссии, Восточной Украины и оккупированных районов России; с весны до конца 1942 г., когда было убито большинство евреев западных районов Украины и Белоруссии и южных районов России, оккупированных летом 1942 г.; с начала 1943 г. до изгнания немцев со всей оккупированной советской территории, когда были уничтожены все оставшиеся евреи ${ }^{3}$.

Как мы видим, в основе этой периодизации находятся количественные изменения. Эти изменения, несомненно, важны, так как именно они приводят к изменениям качественным, однако считать именно количественные изменения основой, критерием периодизации Холокоста в СССР (как, впрочем, какого-либо иного события или явления), совершенно некорректно - в основе периодизации должны находиться не количественные, а качественные изменения. Таким качественным скачком, отделяющим один период Холокоста в СССР от другого, явился, на наш взгляд, переход от расстрелов еврейской интеллигенции (как потенциальной руководящей силы сопротивления политике истребления), евреев - функционеров компартийного и советского аппарата, евреев-мужчин (как возможной движущей силы сопротивления политике истребления) к поголовному истреблению евреев. Больше качественных скачков в Холокосте в СССР не наблюдалось. Происходили только количественные изменения, то есть множились населенные пункты, районы, области, «свободные от евреев».

\section{Когда произошел качественный скачок в Холокосте в СССР?}

В разных оккупированных регионах СССР указанный выше качественный скачок (переход к поголовному истреблению евреев) произошел не одномоментно, а в разное время. Первое массовое уничтожение евреев состоялось в районе деятельности оперативной команды 2 (Einsatzkommando 2) («фюрер» - штурмбаннфюрер СС Рудольф Батц) - в Латвии (кроме района Даугавпилс) и в прилегающих к Латвии районах Литвы (Биржайский, Мажейкяйский, Шяуляйский и, вероятно, Тельшяйский). Уже 11 июля 1941 г. в городе Ауце (тогда Елгавский уезд, ныне Добельский район) отряд латышской

${ }^{3}$ Ицхак Арад, ред., Уничтожение евреев СССР в годы немецкой оккупации (1941-1944): сборник документов и материалов (Иерусалим: Яд Ва-Шем, 1991), 9; Ицхак Арад, Катастрофа евреев на оккупированных территориях Советского Союза (1941-1945) (Днепропетровск: Центр «Ткума», ЧП «Лира ЛТД»; Москва: Центр «Холокост», 2007), 197. 
«самоохраны» и группа немцев, приехавших из Елгавы“, расстреляли поголовно всех евреев, оставшихся в оккупации,- 99 чел. - мужчин, женщин и детей ${ }^{5}$. Расстрел всех евреев в Ауце не был исключением или «дикой» акцией. Так, 12 июля были убиты все евреи в Добеле 18 июля - в Акнисте', 19 июля - в Виесите ', 21 июля - в Субате', 21-22 июля - в Илуксте ${ }^{10}, 28$ июля - в Силене". Во второй половине июля 1941 г. были также уничтожены все евреи в Елгаве и окрестностях (1550 чел., в том числе 1200 из Елгавы) $)^{12}$, в Тукумсе ${ }^{13}$, в Канда-

${ }^{4}$ Скорее всего, речь идет об отряде оперативной команды 2. Сама команда в то время находилась в Риге, а один из ее отрядов - в Елгаве (Mitau). Этот отряд (около 20 чел.) возглавлял штурмшарфюрер СС Альфред Беку (Alfred Becu). Bundesarchiv (далее - BArch) B162/19407, Anklage ZSt Dortmund $45 \mathrm{Js}$ 18/65 gg., Becu und Adelt; BArch B162/14317, Urteil LG Köln 24 Ks

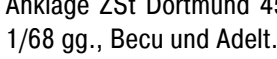

${ }^{5}$ Государственный архив Российской федерации (далее - ГАРФ), ф. 7021, оп. 93, д. 2410, л. 272-285 (показания свидетелей); Rudïte Vïksne, "Ebreju iznīcināšana Aucē 1941 gada jūlijā”, in Holokausta izpētes jautāiumi Latvijā: starptautiskā semināra refenāti 2001 gada 29 novembris, Rīga,

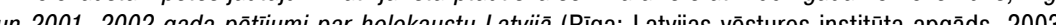
un 2001-2002 gada pêtijumi par holokaustu Latvijā (Rīga: Latvijas vēstures institūta apgāds, 2003), 101-126. В монографии Andrew Ezergailis, The Holocaust in Latvia 1941-1944: The Missing Center (Riga: Historical Institute of Latvia, in association with the United States Holocaust Memorial Museum Washington, D.C., 1996) об акции в Ауце не упоминается вообще, хотя именно с нее началось тотальное истребление евреев.

${ }^{6}$ ГАРФ, Ф. 7021, оп. 93, д. 2410, л. 292 (акт от 30 июня 1945 г.), л. 296-307 (показания свидетелей); Мейер Мелер, Места нашей памяти: еврейские общины Латвии, уничтоженные в Холокосте (Рига: Рижская еврейская община, Музей «Евреи Латвии», 2010), 156. Расстреляны были 48 чел. (18 мужчин, 17 женщин и 13 детей).

${ }^{7}$ Мелер, Места нашей памяти, 25-29.

8 «Виесите», в Российская Еврейская Энциклопедия (Москва, 2000), 4:239; Мелер, Места нашей памяти, 97

${ }^{9}$ Григорий Смирин, «Субате», в Холокост на территории СССР: энциклопедия, ред. Илья Альтман (Москва: РОССПЭН, 2009), 953.

${ }^{10}$ Иосиф Рочко, «Илуксте», в Холокост на территории СССР: энциклопедия, ред. Илья Альтман (Москва: РОССПЭН, 2009), 347. Вместе с местными евреями были также расстреляны несколько сот евреев-беженцев из Литвы.

11 Григорий Смирин и Мейер Мелер, «Боровка в Латвии», Лехаим: ежемесячный литературнопублицистический журнал, № 10 (114) (2001): 18-21. Евреи были арестованы 22 июля 1941 и помещены в синагогу. Расстрел был произведен 28 июля 1941 г. членами местного отряда «самообороны».

${ }_{12}$ BArch B162/435, Ereignismeldung UdSSR, № 40 (от 1 августа 1941 г.); BArch B162/19407, Anklage ZSt Dortmund $45 \mathrm{Js}$ 18/65 gg., Becu und Adelt; BArch B162/14317, Urteil LG Köln 24 Ks 1/68 gg., Becu und Adelt; Andris Tomašūns, "Jelgavā nogalinātie ebreji: padomju un nacistu dati», in Holokausts Latvijā: starptautiskās konferences materiāli 2004 gada 3-4 jūniiss, Rīga, un 2004-2005 gada pētījumi par holokaustu Latvijā (Rīga: Latvijas vēstures institūta apgāds, 2006), 162-183.

${ }_{13}^{13}$ ГАРФ, ф. 7021, оп. 93, д. 134, л. 10-25 (показания свидетелей); Максим Марголин, Холокост в Латвии: «Убить всех евреев!» (Москва: Вече, 2011), 288. ве $^{14}$, в Стенде ${ }^{15}$ и, вероятно, в Кулдиге ${ }^{16}$ и в Салдусе ${ }^{17}$. Отряд оперативной команды 2 в Шяуляй (Литва) уже 12-13 июля 1941 г. организовал расстрел всех евреев в Плунге (Тельшяйский уезд) ${ }^{18}$, а в третьей декаде июля 1941 г. - всех евреев в Лигумай ${ }^{19}$, Линкуве ${ }^{20}$, Шаукенай ${ }^{21}$.

В районе деятельности (Литва и район Даугавпилса) соседней команды - оперативной команды 3 (Einsatzkommando 3) («фюрер»штандартенфюрер СС Карл Егер) - качественный скачок произошел в середине августа 1941 г. 15-16 августа 1941 г. в Рокишкис отряд этой команды совместно с литовскими «партизанами» произвел поголовное истребление всех евреев, то есть впервые расстрелял не только взрослых евреев, но и детей - в общей сложности 3200 чел $^{22}$. Вместе с тем следует отметить, что отряд этой команды в Даугавпилсе впервые произвел расстрел женщин с детьми уже 2 августа 1941 г. $^{23}$

\footnotetext{
${ }^{14}$ ГАРФ, ф. 7021 , оп. 93 , д. 130, л. 83.

${ }^{15}$ ГАРФ, ф. 7021 , оп. 93, д. 130 , л. 220 с об.

${ }^{16}$ ГАРФ, ф. 7021, оп. 93, д. 2415, л. 85.

${ }^{17}$ ГАРФ, ф. 7021 , оп. 93 , д. 2415, л. $4,12$.
}

${ }^{18}$ См.: BArch B162/9336-9338, Exekution der jüdischen Bevölkerung aus Plunge (Litauen) (ca. 3000 Personen), zum Teil durch Erschießung im Dorf Kauschenai, 1941 durch litauische Partisanen unter deutscher Führung und Erschießung von litauischen, politischen Häftlingen in Plunge; Alexander Kruglov and Geoffrey P. Megargee, «Plunge», in Encyclopedia of Camps and Ghettos, 1933-1945, ed. Geoffrey P. Megargee and Martin Dean (Bloomington, Indianapolis: Indiana University Press, 2012), 2: 1105.

${ }^{19}$ Boleslovas Baranauskas ir Eusiejus Rozauskas, red., Masinès žudynès Lietuvoje, 1941-1944: dokumentu rinkinys (Vilnius: Leidykla «Mintis», 1973), 404. В ходе двух казней убито 190 чел. $(40+150)$. По другим данным (Wolfgang Curilla, Die deutsche Ordnungspolizei und der Holocaust im Baltikum und in Weißrußland 1941-1944 (Paderborn: Schöningh, 2005), 297) расстрел евреев в Лигумай имел место 1 августа 1941 г. (около 500 жертв).

${ }_{20}^{20}$ ГАРФ, Ф. 7021, оп. 94, д. 436, л. 28; «Linkuva», in Lithuanian Jewry (Tel Aviv: Association of Former Lithuanians in Israel, 1984), 4:306; «Linkuva», in Pinkas Hakehillot Lita: encyclopedia of Jewish Communities, Lithuania, ed. Dov Levin and Yosef Rosin (Jerusalem: Yad Vashem, 1996), 362. По другим данным (Boleslovas Baranauskas ir Eusiejus Rozauskas, red., Masinès žudynés Lietuvoje, 1941-1944: dokumenty rinkinys (Vilnius: Leidykla «Mintis», 1973), 404) гетто в Линкуве было ликвидировано 5-7 августа 1941 г. путем расстрела около 500 евреев, причем 300 женщин и детей были расстреляны в Аткоцюнайском (Atkotzyunai) лесу (5 км юго-восточнее Линкуве), а около 200 мужчин в Довариукайском (Dovariukai) лесу (4 км северо-восточнее Линкуве).

${ }^{21}$ "Saukenai», in The Holocaust in 21 Lithuanian Towns, compil. and trans. Joe Woolf, дата обращения 18 Октября, 2018, http://www.jewishgen.org//izkor/lithuania3/lithuania3.html.

${ }^{22}$ См.: Российский государственный военный архив (РГВА), ф. 500, оп. 1, д. 25, л. 83 (отчет Einsatzkommando 3 от 10 сентября 1941 г.).

${ }^{23}$ «Холокост в Даугавпилсе», дата обращения 2 октября, 2018, http://www.gorod.lv/novosti/14248/ holokost_v_daugavpilse. Это были евреи из окрестных населенных пунктов, пригнанные в Даугавпилс (Daugavpils) в конце июля 1941 г. 
Однако для района деятельности оперативной команды 3 это было скорее исключением из правила.

В начале июля 1941 г. также началось поголовное истребление евреев в Белостокской области, входившей в состав БССР с конца 1939 г. Сначала акция производилась путем погромов, в ходе которых в ряде населенных пунктов области было уничтожено почти все еврейское население. Так, в Вонсош (Wąsosz) это произошло 5 июля, в Радзилуве (Radziłów) - 7 июля, в Едвабне (Jedwabne) - 10 июля ${ }^{24}$. Погромы были организованы зондеркомандой («фюрер» - оберштурмфюрер СС Герман Шапер) гестапо Цихенау-Шрёттерсбург (ЦеханувПлоцк), действовавшей, руководствуясь оперативным приказом № 1 шефа полиции безопасности и СД от 29 июня 1941 г., в котором, в частности, говорилось:

Стремлениям $\kappa$ самоочищению антикоммунистических или антиеврейских кругов во вновь оккупированных областях не следует чинить никаких препятствий. Напротив, их следует, конечно, незаметно вызывать, усиливать, если необходимо, и направлять по правильному пути, но так, чтобы эти местные «круги самообороны» позднее не могли сослаться на распоряжения или

${ }^{24}$ BArch B162/278, BI. 113 (№ 541), Befehlshaber des rückw. Heeresgebietes Mitte, Anlagen Sonderband - zum KTB, Zeit: 15.03.- 31.12.1941, Tagesmeldung vom 14.07.1941: «В Кольно (Kolno) и Щучине (Szczuczyn) поляки совершили еврейские погромы»; 10 Tagesmeldung vom 20.07.1941: «В нескольких населенных пунктах близ границы генерал-губернаторства поляки совершили еврейские погромы»; BArch B162/5863, ВI. 69-70, Untersuchungsstelle für Aufklärung von N. S. Gen Aufklärung von N.S. Gewaltverbrechen in früheren Regierungsbezirk Ziechenau, hier: Ciechanow Radzilow und Tykocin; BArch B162/5863, BI. 160-161 (Radzilow), 163-164 (Jedwabne), Zentrale Stelle Ludwigsburg, Abschlussbericht v. 17.03.1964 im Vorermittlungsverfahren 5 AR-Z 13/62 gegen Schaper u.a.; BArch B162/5863, BI. 196-198, Staatsanwaltschaft Hamburg, Vermerk v. 2.09.1965 im Verfahren 141 Js 223/64 gegen Schaper u.a.; Jan Tomasz Gross, Neighbors: the destruction of the Jewish community in Jedwabne (Poland, N.J.: Princeton University Press, 2001); Lech Z. Niekrasz, Opergromy i mordy ludności żydowskiej w Łomżyńskiem i na Białostocczyźnie latem 1941 roku w świetle relacji ocalałych Żydow i dokumentow sądowych», in Wokół Jedwabnego, red. Pawło Machcewicz i Krzysztof Persak (Warszawa: Instytut Pamięci Narodowej, 2002), 1:167-168 (Kolno), 169-171 (Wąsosz), 231-259 (Radziłów) Edmund Dmitrów, «Oddzialy operacyjne niemieckiej Policji Bezpieczeństwa i Służby Bezpieczeństwa a początek zagłady Żydow w Łomżyńskiem i na Białostocczyźnie latem 1941 roku», in Wokół Jedwabnego, red. Pawło Machcewicz i Krzysztof Persak (Warszawa: Instytut Pamięci Narodowej, 2002) 1.323-350; Andrzej Rzepliński, «Te jest z ojczyzny mojei? Sprawy karn żydó w J Andze Mzach Zydów w Jedwabnem w świetle zasady rzetelnego procesu", in Wokół Jedwabnego, red. Pawło Machcewicz i Krzysztof Persak (Warszawa: Instytut Pamięci Narodowej, 2002), 1: 353-459; Jan Tomasz Gross, Wokót «Sąsiadyw»: polemiki i wyjasnienia (Sejny: Pogranicze, 2003); Edmund Dmitryw, Pawe Machcewicz und Tomasz Szarota, Der Beginn der Vernichtung: zum Mord an den Juden in Jedwabne und Umgebung im Sommer 1941 (Osnabrück: Fibre, 2004). данные им политические гарантии... Создания постоянных частей самообороны с иентральным руководством пока следует избегать; вместо них целесообразно вызывать, как разбяснено выше, местные погромы $\iota^{25}$.

Таким образом, произошедшее в начале июля 1941 г. тотальное уничтожение евреев в ряде населенных пунктов области только по форме представляло собой стихийные погромы, а фактически это были заранее спланированные и подготовленные акции.

Погромы были одним из способов решения «еврейского вопроса» в СССР. Однако расчеты полиции безопасности с помощью погромов решить «еврейскую проблему» или хотя бы сделать существенный вклад в ее решение не оправдались. Так, в «Донесении о событиях в CCCР» (Ereignismeldung UdSSR) № 47 от 9 августа 1941 г. сообщается: «Предпринятые в свое время попытки осторожно инспирировать еврейские погромы, к сожалению, не дали желаемого результата» ${ }^{26}$. В «Донесении о событиях в СССР» № 81 от 12 сентября 1941 г. отмечалось, что «К активным шагам против евреев население почти нигде склонить не удалось» ${ }^{27}$. Правда, в Западной Украине и в Белостокской области в ряде небольших населенных пунктов путем погромов были уничтожены почти все евреи ${ }^{28}$, однако в целом количество жертв погромов было незначительным, в связи с чем

${ }^{25}$ Peter Klein, ed., Die Einsatzgruppen in der Sowjetunion 1941/42: die Täigkeits- und Lageberichte des Chefs der Sicherheitspolizei und des SD (Berlin, 1997), 319.

${ }^{26}$ BArch B162/435, BI. 231.

${ }^{27}$ BArch B162/437, BI. 46.

${ }^{28} \mathrm{CM}$.: Andrzej Żbikowski, «Lokalne pogromy żydow w czerwcu i lipcu 1941 roku na wschodnich rubieżach \|l Rzeczypospolitej», Biuletyn Żydowskiego Instytutu Historycznego, no. 2-3 (1992); Żbikowski, «Pogromy i mordy ludności żydowskiej w Łomżyńskiem i na Białostocczyźnie latem 1941 roku», 159271; А. Круглов, «Погромы в Восточной Галиции летом 1941 г.: организаторы, участники, масштабы и последствия", в Война на уничтожение: нацистская политика геноцида на территории Восточной Европы: материалы международной научной конференции, Москва, 26-28 апреля 2010 (Москва: Фонд «Историческая память», 2010), 324-341; Александр Круглов, «Погромы в Восточной Галиции лета 1941 г.: организаторы, участники, масштабы и последствия», Проблеми історії Голокосту: науковий журнал, № 5 (2010): 56-74; Kai Struve, «Rites of Violence? The Pogroms of Summer 1941», Polin: Studies in Polish Jewry 24 (2012): 257-274; Witold Mędykowski, W cieniu gigantów: pogromy 1941 r. w byłej sowieckiej strefie okupacyjnej: kontekst historyczny, społeczny i kulturowy (Warszawa: PAN, 2012); Dieter Pohl, "Anti-Jewish pogroms in Western Ukraine: a research agenda", in Shared history - divided memory: Jews and others in Soviet-occupied Poland, 1939-1941, ed. Elazar Barkan, Elizabeth A. Cole and Kai Struve (Leipzig: Leipziger Universitätsverlag GMBN, 2007), 305-313; Elizabeth A. Cole and Kai Struve (Leipzig: Leipziger Universitätsverlag GMBN, 2007), 305-313;
Andrzej Żbikowski, «Pogroms in northeastern Poland: spontaneous reactions and German instigations», in Shared history - divided memory: Jews and others in Soviet-occupied Poland, 1939-1941, ed. Elazar Barkan, Elizabeth A. Cole and Kai Struve (Leipzig: Leipziger Universitätsverlag GMBN, 2007), 315-354; Christoph Dieckmann, «Lithuania in summer 1941: the German invasion and the Kaunas pogrom», 
такой способ уничтожения евреев с конца июля - начала августа 1941 г. фактически перестал применяться.

В первые дни августа 1941 г. произошел качественный скачок в Западной Белоруссии: 2-3 августа 1941 г. в деревнях Хомск и Мотоль (соответственно Дрогичинский и Ивановский районы Брестской области) впервые были расстреляны все евреи ${ }^{29}$. Унитожение евреев в этих деревнях отнюдь не было результатом погромных действий, это была заранее спланированная акция, проведенная конным дивизионом (Reitende Abteilung) (командир - штурмбаннфюрер СС Густав Ломбард) 1-го кавалерийского полка СС (командир штандартенфюрер СС Герман Фегелейн) согласно соответствующему приказу Генриха Гиммлера. О существовании такого документа мы узнаем из приказа № 42 по 1-му кавалерийскому полку СС от 27 июля 1941 г. В последнем со ссылкой на «особое распоряжение рейхсфюрера СС», в частности, предписывалось: «С евреями следует обращаться в основном как с грабителями. Исключение составляют только специалисты, как пекари и пр., и прежде всего врачи» ${ }^{30}$. «Обращение как с грабителями» на нацистском сленге означало расстрел. Радиограмма 2-го кавалерийского полка СС, датированная 1 августа 1941 г., 10:00, и адресованная конному дивизиону этого полка, уточняла и требовала:

Категорический приказ РФ СС [рейхсфюрера $C$ - авт.]. Все евреи должны быть расстреляны. Еврейских женщин загнать в болото ${ }^{31}$.

Подобную радиограмму получил и конный дивизион 1-го кавалерийского полка СС, командир которого, штурмбаннфюрер СС Г. Ломбард, в приказе № 28 по конному дивизиону от 1 августа 1941 г., оценил ее так:

...сегодняшнюю радиограмму к-ра [командира] отн.[осительно] расстрела евреев не следует рассматривать как выговор, так как до сих пор в деревнях евреев не было. Еврейские деревни до сих пор все в районе деятельности 2-го полка. Исключение - Береза-Картузская.

in Shared history - divided memory: Jews and others in Soviet-occupied Poland, 1939-1941, ed. Elazar Barkan, Elizabeth A. Cole and Kai Struve (Leipzig: Leipziger Universitätsverlag GMBN, 2007), 355-385.

${ }^{29}$ "Chomsk", in The Yad Vashem Encyclopedia of the Ghettos During the Holocaust, ed. Guy Miron (Jerusalem, 2009), 1: 114; Martin Dean, "Chomsk», in Encyclopedia of Camps and Ghettos, 19331945, ed. Geoffrey P. Megargee and Martin Dean (Bloomington, Indianapolis: Indiana University Press, 2012), 2: 1341-1342; Aaron Leib Poliak, Hurban Motele (The Destruction of Motele), ed. Dr. Dov Yarden (Jerusalem: Council of Motele Immigrants, 1956).

${ }^{30}$ BArch B162/20212, BI. 793-796.

${ }^{31}$ Bundesarchiv-Militärarchiv, RS3-8/36. 221-й див.[изии] срочно необходимы евреи для ремонта роллбана. Несмотря на это, особенно командиров дозорных групп следует еще раз строжайше проинструктировать. В населенных пунктах в жмивых не должно остаться ни одного еврея-мужчины, ни одной еврейской семьи

Во второй половине августа 1941 г. началось поголовное истребление евреев в районе деятельности оперативной группы B (Einsatzgruppe B) (Восточная Белоруссия и западные области России). Так, в Зембине (Борисовский район Минской области) 18 августа 1941 г. были расстреляны все оставшиеся в оккупации евреи - 760 чел., в том числе более 250 детей $^{33}$. Примерно тогда же, а, возможно, даже на несколько дней раньше - 12 августа 1941 г. $^{34}$ - были уничтожены все евреи (свыше 600 чел.) в городе Сураж (Витебская область) ${ }^{35}$.

Британский историк Алекс Дж. Кай (Alex J. Кау) утверждает, что в районе деятельности оперативной группы $B$ качественный скачок произошел в конце июля 1941 г., когда в Вилейке оперативная команда 9 уничтожила всех евреев ${ }^{36}$. При этом он, в частности, ссылается на оперативный отчет № 2 оперативных групп полиции безопасности и СД (Tätigkeits- und Lagebericht № 2 der Einsatzgruppen der Sicherheitspolizei und des SD in der UdSSR) (отчетный период 29 июля - 14 августа 1941 г.), в котором говорится: «В Вилейке должно было быть ликвидировано все еврейство» («In Vileyka musste die gesamte Judenschaft liquidiert werden»). Однако анализ соответствующих донесений о событиях в СССР (месячные и двухнедельные оперативные отчеты составлялись на основе донесений о событиях за соответствующий период) позволяет сделать вывод, что в данном случае в оперативном отчете № 2 явно пропущено одно слово, которое содержится в соответствующем «Донесении о событиях в СССР». Так, в «Донесении о событиях в СССР» № 50 от 12 августа 1941 г. сообщается: «В Вилейке проходившей командой уже ликвидированы

${ }^{32}$ Bundesarchiv-Militärarchiv, RS4/441.

${ }_{33}^{3}$ ГАРФ, ф. 7021, оп. 87, д. 4, л. 6; Леонид Смиловицкий, Катастрофа евреев в Белоруссии, 19411944 гr. (Тель-Авив: Библиотека Матвея Черного, 2000), 177.

34 «Urteil LG Berlin, 3 PKs 1/62, v. 22.6.1962 gg. Filbert u.a»., Justiz und NS-Verbrechen: Samm/ung deutscher Strafurteile wegen nationalsozialistischer Tötungsverbrechen 1945-1966 (Amsterdam, 1968), 18: 620. Количество жертв - самое меньшее 200 чел.

${ }_{35}$ ГАРФ, Ф. 7021 , оп. 84 , д. 13, л. 1-8, 11, 137-145. Согласно материалам ЧГК акция имела место уже 2 августа 1941 г. Количество жертв, возможно, преувеличено, так как согласно переписи населения 1939 г. в Сураже жил 461 еврей.

${ }^{36}$ Alex J. Kay, «Transition to Genocide, July 1941: Einsatzkommando 9 and the Annihilation of Soviet Jewry", in Holocaust and Genocide Studies 27, no. 3 (Winter 2013): 424-425. 
все евреи мужского пола» («In Wilejka war bereits durch das dort durchziehende Kommando die gesamte männliche Judenschaft liquidiert worden» $)^{37}$, то есть в оперативном отчете № 2 пропущены слова «мужского пола». Таким образом, нельзя утверждать, что в Вилейке оперативная команда 9 уничтожила всех евреев. Женщины с детьми были оставлены в живых и к декабрю 1941 г. согнаны в гетто. 3 марта 1942 г. в Вилейке было ликвидировано так называемое «детское гетто», и в 1942-1943 гг. были расстреляны и сожжены и все остальные евреи $^{38}$.

Нельзя также согласиться и с утверждением А. Кая, что оперативная команда 9 «была не только первой командой в составе оперативной группы В, начавшей убивать женщин и детей, но фактически вообще первой командой из состава всех оперативных групп, которая это сделала» ${ }^{39}$.Как мы уже доказали выше, первой командой, которая истребляла женщин и детей уже в начале июля 1941 г., была оперативная команда 2 из состава оперативной группы А.

Во второй половине августа 1941 г. также началось поголовное истребление евреев в Украине - в районах деятельности оперативных групп С и D. Впервые этот качественный скачок произошел в городах Белая Церковь и Каменец-Подольский ${ }^{40}$ Немецкий историк КлаусМихаэль Маллман (Klaus-Michael Mallmann) считает, что именно акция в Каменец-Подольском 26-28 августа 1941 г. «с ее 23600 жертвами ознаменовала не только количественный, но и качественный скачок в процессе массового убийства европейских евреев вследствие перехода от политики избирательного истребления к тотальному уничтожению»". Мнение К.-М. Маллмана разделяет и другой известный немецкий историк и исследователь Холокоста Дитер Поль (Dieter Pohl), который акцию в Каменец-Подольском оценивает как

\footnotetext{
${ }^{37}$ BArch B162/435, BI. 266.

${ }^{38}$ Alexander Kruglov and Martin Dean, «Wilejka», in Encyclopedia of Camps and Ghettos, 1933-1945, ed. Geoffrey P. Megargee and Martin Dean (Bloomington, Indianapolis: Indiana University Press, 2012), 2: $1299-1300$.

${ }^{39}$ Kay, «Transition to Genocide, July 1941», 425.

${ }^{40}$ Klaus-Michael Mallmann, «Der qualitative Sprung im VernichtungsprozeB: Das Massaker von Kamenez-Podolsk Ende August 1941", Jahrbuch für Antisemitismusforschung 10 (2001): 239-264 Michael Wildt, Kamenez-Podolsk, Handlungsoptionen und Radikalisierung in der nationalsozialistischen Mordpraxis im Krieg gegen die Sowjetunion im Sommer 1941 (рукопись, архив автора); Александр Круглов, Потери евреев Украины в 1941-1944 гг. (Харьков: Тарбут Лаам, 2005), 102; Александр Круглов, «Еврейская акция» в Каменец-Подольском в конце августа 1941 г. в свете немецких доКруглов, ««врейская акция» в Каменец-Подольском в конце августа 1941

${ }^{41}$ Mallmann, «Der qualitative Sprung im Vernichtungsprozeß», 239.
}

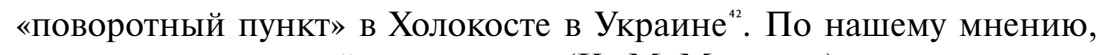
вести речь о «европейских евреях» (К.-М. Маллман) в данном случае некорректно: решение о физическом истреблении европейского еврейства (точнее западноевропейского) Адольф Гитлер принял только в первой половине декабря $1941 \mathrm{r.}^{43}$ Говорить можно только о евреях Советского Союза, однако, как мы показали выше, качественный скачок в Холокосте на оккупированной территории СССР произошел уже 11 июля 1941 г., а «еврейская акция» в Каменец-Подольском отличалась от акции в Ауце только количественными показателями. Если же брать только Украину, то на ее территории качественный скачок произошел не в Каменец-Подольском, а в Белой Церкви, где расстрелы еврейских детей «украинской милицией по распоряжению СД» начались уже 19 августа 1941 г., ${ }^{44}$ то есть за неделю до акции в Каменец-Подольском.

Американский историк Кристофер Браунинг (Christopher Browning) соотносит качественный скачок с расстрелом еврейского населения, «включая женщин и детей» ${ }^{45}$ в городе Шепетовка, который произвел в конце июля 1941 г. 45-й резервный полицейский батальон из состава полицейского полка «Юг». Мы не можем согласиться с этим утверждением ${ }^{46}$. В Шепетовке действительно 28 июля

${ }^{42}$ Dieter Pohl, «Schauplatz Ukraine: Der Massenmord an der Juden im Militärverwaltungsgebiet und im Reichskommissariat 1941-1943», in Ausbeutung, Vernichtung, Öffentlichkeit. Neue Studien zur nationalsozialistischen Lagerpolitik, hrsg. von Norbert Frei, Sybille Steinbacher und Bernd Wagner (München De Gruyter Saur, 2000), 143; Dieter Pohl, «The Murder of Ukraine's Jews under German Military Administration and in the Reich Commissariat Ukraine», in The Shoah in Ukraine: History, Testimony, Memorialization, ed. Ray Brandon and Wendy Lower (Bloomington: Indiana University Press, 2008), 32. ${ }^{43}$ CM.: Christian Gerlach, «Die Wannsee-Konferenz, das Schicksal der deutschen Juden und Hitlers politische Grundsatzentscheidung alle Juden Europas zu ermorden», WerkstattGeschichte 18 (1997): 7-44; Götz Aly, «Der 12 Dezember 1941», Berliner Zeitung 13 (Dezember 1997); Christian Gerlach, «The Wannsee Conference, the Fate of German Jews, and Hitler's Decision in Principle to Exterminate All European Jews", Journal of Modern History (December 1998): 759-812; Christian Gerlach, Krieg Ernährung Völkermord. Deutsche Vernichtungspolitik im Zweiten Weltkrieg (München: Pendo Zürich, Ernährung Völkermord. Deutsche Vernichtungspolitik im Zweiten Weltkrieg (München: Pendo Zürich, 1941/42 (Hamburg: Hans Christians Verlag, 1999), 294.

${ }^{44}$ CM.: Helmuth Groscurth, Tagebücher eines Abwehroffiziers 1938-1940 (Stuttgart: DVA, Deutsche Verlagsanstalt, 1970), 534-537 (отчет от 21 августа 1941 г.).

${ }^{45}$ Christopher Browning, Ordinary men: Reserve Police Battalion 101 and Final Solution in Poland (New York: Penguin books, 1992), 18; Christopher Browning, «Hitler and the Euphoria of Victory: The path to the Final Solution", in The Final Solution: origins and implementation, ed. David Cesarani (London, New York: Routledge, 1994), 140-141.

${ }^{46}$ K. Браунинг к тому же путает фамилии командира полицейского полка «Юг» и командира 45-го батальона. Командиром полка был не «полковник Бессер», а полковник полиции Герман Франц, а командиром 45-го батальона был не «майор Франц», а майор полиции Мартин Бессер. 
1941 г. 2-я рота 45-го резервного полицейского батальона произвела расстрел евреев, однако жертвами были в основном евреи-мужчины (свыше 800 чел.), детей среди расстрелянных не было ${ }^{47}$. Расстрел в Шепетовке был произведен явно в рамках «акции по чистке в районе долины реки Случь, Мирополя, Шепетовки, Заслава, Острога, долины реки Горынь, Гощи» 28-30 июля 1941 г. Акцией руководил «высший фюрер СС и полиции» в тылу группы армий «Юг» обергруппенфюрер СС Фридрих Еккельн (Friedrich Jeckeln), командный пункт которого находился в Шепетовке. В ходе акции, которую проводила 1-я мотопехотная бригада СС, а в качестве оперативного резерва были задействованы два полицейских батальона (45-й и 303-й), расстреляны 1685 евреев, в том числе 59 женщин, «которые оказывали большевистской системе значительную поддержку и выдавали украинцев большевистским власть имущим» ${ }^{4}$. На Шепетовку приходится примерно половина всех расстрелянных евреев.

Бывший «фюрер» оперативной команды 5 (оперативная группа С) Эрвин Шульц на одном из послевоенных допросов показал, что устный приказ о поголовном истреблении евреев он получил в первой трети августа 1941 г.

[...] Еще в июле 1941 г. я получил от шефа моей оперативной группы, д-ра Раша, приказ расстреливать всех евреев, которые не используются на работах, так как они представляют смертельную опасность в тылу сражающихся войск. Приказ я понял так, что он касается евреев мужского пола. Как мне помнится, д-р Раш сослался на распоряжение фюрера. В первой трети августа 1941 г." в Житомире д-р Раш отдал приказ наряду с евреями мужского пола расстреливать также женщин и детей, чтобы немецкому

${ }^{47}$ См.: Архив прокуратуры Регенсбурга, Обвинительное заключение прокуратуры Регенсбург от 2 февраля 1970 г. по делу Розенбауэра, Бессера и Кройцера; Олександр Деко, Кедойшім. Повістьхроніка Шепетівського гетто (Київ, 1995), 32.

${ }^{48} \mathrm{C}$..: Fritz Baade, hrsg., Unsere Ehre heißt Treue: Kriegstagebuch des Kommandostabes Reichsführer SS. Tätigkeitsberichte der 1. und 2. SS-Inf. Brigade, der 1. SS-Kav.-Brigade und von Sonderkommandos der SS (Frankfurtam-Man, WT. Zuich: Europa-VIg., 1965), 95-96 (0 mandos der SS (Frankfurt-am-Main, Wien, Zürich: Europa-Vlg., 1965), 95-96 (отчет о деятельности 1-й мотопехотной бригады СС 27-30 июля 1941 г.); Bernd Boll, «Aktionen nach Kriegsbrauch. Wehrmacht und 1. SS-Infanteriebrigade 1941", Zeitschrift für Geschichtswissenschaft 48, no. 9 (2000): 775 (радиограмма Ф. Еккельна в штаб 6-й армии 31 июля 1941 г.); BArch, RH20-6/111, BI. 132135 (отчет Ф. Еккельна от 1 августа 1941 г.); Bert Hoppe und Hildrun Glass, hrsg., Die Verfolgung und Ermordung der europäischen Juden durch das nationalsozialistische Deutschland 1933-1945 (München: Oldenbourg Wissenschaftsverlag, 2011), 7: 223-225.

${ }^{49}$ Точнее - 10 августа 1941 г. См.: Trials of war criminals before the Nuernberg Military Tribunals under Control Council Law no. 10 (Washington, 1950), 4: 519 (приговор военного трибунала II США от 10 апреля 1948 г.). народу не грозила месть. Этот приказ он получил от $\mathrm{HSSPF}^{\circ 0} \mathrm{E \kappa}$ кельна. Уверен, что д-р Раш сказал: по поручению рейхсфюрера СС. Я не могу сказать точно, присутствовали ли другие руководители оперативных команд нашей оперативной группы, кроме Блобеля и д-ра Крёгера, когда д-р Раш отдал мне приказ ${ }^{\text {s! }}$

\section{О чем говорит начало поголовного истребления евреев уже в начале июля 1941 г.?}

Тот факт, что поголовное истребление евреев началось уже в начале июля 1941 г., говорит, по нашему мнению, о том, что принципиальное решение об уничтожении советских евреев как евреев большевистских было принято, скорее всего, до нападения Германии на СССР. Это подтверждает большинство переживших войну и допрошенных бывших «фюреров» команд СД. В частности, шеф оперативной группы $D$ Отто Олендорф после войны так изложил суть отданных приказов:

Во время формирования оперативных групп в Дюбене в Саксонии перед началом кампании против России оперативные группы и оперативные команды наряду с обычными задачами по линии абвера и информационной службы получили дополнительный приказ - в целях безопасности убивать политических комиссаров, коммунистических активистов, евреев, цыган и всех тех лии, которые угрожают безопасности. При издании приказа - и неоднократно в Берлине, и позднее в других местах - было добавлено, что вермахт об этих задачах информирован и получил указание поддержсвать их выполнение. Как при оглашении этого приказа об убийствах, так и во время дискуссии о нем, вызванной сильными протестами против приказа, [шеф І управления - управления кадров - Главного имперского управления безопасности] Штрекенбах, который передал приказ, подчеркнул, что этот документ является непосредственным распоряжением фюрера и поэтому всякая дискуссия о нем бессмысленна. Убийства, которые совершали члены оперативных групп в 1941 г. и в последующие годы, были, таким образом, не дикими акциями или актами произвола, а планомерной деятельностью по исполнению приказа, отданного фюрером [... $]^{52}$.

\footnotetext{
${ }^{50}$ HSSPF (Höherer SS- und Polizeiführer) - (пер. с нем.) высший фюрер СС и полиции.

${ }^{51}$ См.: BArch B162/20216, BI. 13 (показания бывшего «фюрера» оперативной команды 5 Э. Шульца 25 ноября 1960 г.
}

${ }^{52}$ См.: BArch B162/3300, BI. 2047-2048 (показания О. Олендорфа 9 ноября 1948 г.). 
Бывший «фюрер» зондеркоманды 7a Вальтер Блуме на одном из послевоенных допросов заявил:

[...] Было два совещания, на которых шла речь о деятельности в России. Первое совещание провел Гейдрих в Берлине в РСХА; другое было в Претцше, на нем присутствовали шеф IV управления Мюллер и шеф I управления Штрекенбах [...]. По моему мнению, сначала было совещание в Берлине, которое провел Гейдрих. На этом совещании речь шла о России, и Гейдрих дал описание вещей, которые ожидают там оперативные группы; вопрос об уничтожении восточного еврейства был предметом очень краткого изложения. Речь Гейдриха касалась в первую очередь ожидаемых стычек с партизанами. Этому было уделено основное внимание. В рамках этого изложения он затем заявил, что восточное еврейство как духовный резервуар мирового большевизма в этом случае должно быть уничтожено [...]. На совещании в Берлине не было никакой возможности для дискуссии, она была тогда невозможна. Я еще припоминаю, что возникло беспокойство, когда был объявлен приказ, и кто-то сзади выкрикнул: «Как такое должно происходить?!. На это Гейдрих заявил: «Это вы узнаете из собственного опыта на месте». Такой выкрик с места был совершенно необычным, поэтому он мне запомнился $[\ldots]^{53}$.

В изложении бывшего «фюрера» оперативной команды 3 К. Егера, который также присутствовал на этом совещании, упомянутый эпизод выглядел следующим образом: когда Рейнхард Гейдрих объявил, что в случае войны с Россией евреи на Востоке должны быть расстреляны, один из участников совещания спросил: «Mы что, должны расстреливать евреев?», Р. Гейдрих ответил, что это само собой разумеется ${ }^{\text {s4 }}$.

«Коллега» К. Егера, «фюрер» зондеркоманды $4 a$ штандартенфюрер СС Пауль Блобель на допросах 28 и 29 октября 1947 г. показал, что 17 или 18 июня 1941 г. все офицеры были вызваны в школу фюреров полиции безопасности, где группенфюрер СС Бруно Штрекенбах объявил им следующее:

С этого момента вы все, унтерфюреры и рядовые, которые откомандированы сюда, находитесь под действием закона военного времени. Для вас вступают в силу все предписания, которые

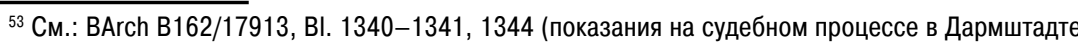
по делу бывших членов зондеркоманды $4 a 4$ марта 1968 г., бывшего командира зондеркоманды $7 a$ В. Блуме)

${ }^{54}$ См.: BArch B162/2503, BI. 193 (1887) (показания К. Егера 15 июня 1959 г.). должен соблюдать солдат на поле боя. Вы все присягаете фюреру. Вы должны, как любой солдат фюрера, выполнять задачи, которые я теперь объявляю, в противном случае к вам будут приняты меры согласно законам военного времени. По приказу фюрера формируются оперативные группы и делятся на команды. Эти оперативные группы во время предстоящего похода на Восток будут подчиняться командуюшим армиям. Ваши задачи следующие: совместно с вермахтом производить захват всех элементов, которые угрожают безопасности. К этим лицам относятся члены НКВД, политические активисты, функционеры, агенты коммунистической партии, а также евреи. Офицеры отвечают за дисциплину своих подчиненных. Фюреры оперативных групп имеют право применять нормы уголовного права. При сотрудничестве с вермахтом с вашей стороны строжайше следует уделять особое внимание личному поведению и дисииплине во время продвижения и при выполнении задач ${ }^{55}$.

На уточняющий вопрос «Поняли ли вы приказ Штрекенбаха так, что должны быть расстреляны все евреи?» П. Блобель ответил: «Да». «Было ли вам Штрекенбахом категорически сказано, что, по крайней мере, часть вашей деятельности будет состоять в убийстве безоружных людей?» - П. Блобель ответил: «Да, что касается приказа в отношении евреев, то да...»"

Уже упоминавшийся «фюрер» оперативной команды 2 Р. Батц на допросе 27 января 1961 г. показал:

[...] Нам, как членам партии или СС, были, естественно, известны цели движсения. Кроме того, в Претцше мы еще раз были подробно информированы о наших предстоящих задачах. На обвинение я должен все же заявить, что наши задачи должны были главным образом состоять в том, чтобы обеспечивать безопасность тыла сражающихся войск, то есть, в первую очередь, вести борьбу с партизанами, саботажниками и пр. Это неверно, что, как мне сказано, наши задачи в первую очередь или главным образом состояли в том, чтобы ликвидировать евреев в оккупированных областах [...]. После того как задачи оперативных групп и оперативных команд были мне еще раз доказательно изложены, я скажу следующее: это верно, и нам было известно с самого начала, что к задачам относилась ликвидация еврейской нации. Эта задача была изложена

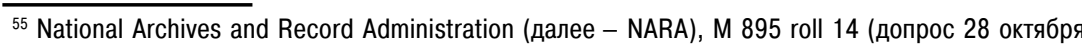
1947 г.).

${ }^{56}$ NARA, M 895 roll 15 (допрос 29 октября 1947 г.). 
нам, фюрерам СС (то есть шефам оперативных групп и команд) в Претише. Хотя уничтожение евреев было одной из задач наших подразделений, наряду с ней имелись две другие задачи, а именно: 1. [борьба с] так назыв. вражеской разведслужббой и 2. борьба с партизанами $[\ldots]^{57}$.

Бывший «фюрер» зондеркоманды $1 a$ Мартин Зандбергер на допросе 3 января 1966 г. также подтвердил наличие приказа об истреблении евреев до нападения Германии на СССР.

[...] Я как штурмбаннфюрер СС весной 1941 г. был откомандирован в Претиш. Там были сформированы оперативные группы и оперативные команды. В то время имели место 2 совещания: одно - в Претцие и другое, несколько позднее, - во дворие Приниа Альбрехта в Берлине. На одном из этих двух совещаний присутствующим офицерам, которые были назначены руководителями оперативных групп и оперативных и зондеркоманд, был передан приказ, предметом которого являлись расстрелы евреев. Сегодня я уже не могу сказать, кто отдал этот приказ - Штрекенбах или Мюллер. Я также не могу сказать, было ли это на совещании в Претцше или в Берлине. По моему мнению, этот приказ мог отдать или передать Мюллер как шеф IV управления. Было сказано, что это так называемый приказ фюрера. Предметом приказа были расстрелы евреев. Я не помню, была ли названа причина, по которой евреи должны быть уничтожены. Кроме того, был объявлен так называемый приказ о комиссарах. В отличие от распоряжения, касающегося расстрела евреев, отданного только в устной форме, имелись письменные экземпляры приказа о комиссарах, которые возможно, были распространены позднее. Насколько я помню, на одном из совещаний Штрекенбах прочитал список, который содержал имена и распределение отдельных офицеров. На совещании также присутствовали те офицеры, которые были назначены в качестве руководителей отделов III и IV в штабах оперативных групп $[. . .]^{\text {s8 }}$

Показания В. Блуме, К. Егера и П. Блобеля подтверждают показания еще одного бывшего «фюрера» команды СД - Пауля Цаппа:

Это могло быть незадолго до выступления команды, когда в Претцше состоялось совещание офицеров. Я хотел бы это совещание обозначить скорее как собрание. Присутствовали ли на нем все офицеры или только руководители отдельных команд, я сказать не могу. Однако с большой вероятностью могу предположить, что

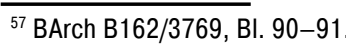

${ }^{58}$ BArch B162/5658, BI. 174. на этом собрании присутствовали все офицеры; к этому я прихожс, исходя из большого количества участников. На собрании с докладом или речью о будущих задачах оперативных команд выступил Гейдрих. Задачи были обозначены Гейдрихом примерно в той же форме, в какой они определены в соглашении между вермахтом и РСХА. В заключение все присутствовавшие были приведены к присяге фюреру как верховному главнокомандующему. Затем был оббявлен приказ фюрера, согласно которому оперативные команды на охраняемой территории должны уничтожить всех евреев [...]".

Немецкий историк Ральф Огоррек (Ralf Ogorreck) на основе анализа событий в районах деятельности различных команд СД, а также на основе анализа послевоенных показаний бывших руководителей этих команд приходит к выводу, что переход к тотальному уничтожению евреев на оккупированной территории СССР произошел в середине августа 1941 г.; при этом Р. Огоррек связывает этот переход с инспекционной поездкой Г. Гиммлера в Минск 15 августа 1941 г., в ходе которой он, предположительно, отдал приказ убивать не только евреев-мужчин, но также женщин и детей ${ }^{60}$. Эту точку зрения разделяют немецкие историки Христиан Герлах ${ }^{61}$, Ульрих Херберт ${ }^{62}$, Юрген Маттеус ${ }^{63}$ и некоторые другие исследователи. Мы не можем согласиться с этим предположением. Во-первых, Р. Огоррек даже при анализе событий в районах деятельности команд СД не анализирует события в районе деятельности оперативной команды 2 (возможно, потому, что эти события не укладываются в его схему). Во-вторых, он фактически не учитывает тот факт, что большинство переживших войну руководителей команд СД, участвовавших в совещаниях в Берлине и в Претцше в июне 1941 г., в своих показаниях утверждали, что устный приказ о тотальном уничтожении евреев в СССР был отдан накануне нападения Германии на СССР. В-третьих, по нашему

${ }^{59}$ См.: BArch B162/1231, B. 3981 -3982 (протокол допроса бывшего руководителя зондеркоманды 11а П. Цаппа 3 января 1968 г.).

${ }^{60} \mathrm{CM}_{\mathrm{M}}$ : Ralf Ogorreck, Die Einsatzgruppen und die «Genesis der Endlösung» (Berlin: Metropol-Verl., 1996).

${ }^{61}$ Gerlach, «Die Wannsee-Konferenz», 9.

62 Ulrich Herbert, «Vernichtungspolitik: Neue Antworten und Fragen zur Geschichte des Holocaust», in Nationalsozialistische Vernichtungspolitik 1939-1945: Neue Forschungen und Kontroversen (Frankfurt-am-Main: Fischer, 1998), 49-50.

${ }^{63}$ Jürgen Matthäus, «Operation Barbarossa and the Onset of the Holocaust, June-December 1941", in The Origins of the Final Solution: The Evolution of the Nazi Jewish Policy, September 1939 - March 1942, aut. Christopher Browning (Lincoln: University of Nebraska Press, Jerusalem: Yad Vashem, 2004), 283. 
мнению, для общего вывода о том, когда произошел переход к поголовному истреблению евреев в СССР, необходимо учитывать и события в районах деятельности не только собственно команд СД, но и в районах деятельности других карательных подразделений.

\section{О чем говорит разномоментное претворение в жизнь «приказа} фюрера»?

Тот факт, что поголовное истребление евреев в разных регионах оккупированной советской территории началось не одновременно, объясняется, вероятно, разным отношением «фюреров» команд СД, командиров подразделений войск СС и полиции к этому приказу: одни из них, исходя из собственных убеждений и «собственного жизненного опыта» не торопились выполнять «приказ фюрера», в то время как убеждения и опыт других требовали от них немедленных действий. В качестве примера можно привести поведение «фюреров» оперативных команд 2 (Р. Батц) и 3 (К. Егер). Обе команды входили в одну и ту же оперативную группу, у них был один и тот же непосредственный начальник, они получали одни и те же приказы. Тем не менее, Р. Батц приступил к поголовному истреблению евреев уже 11 июля 1941 г., а К. Егер - только 15 августа 1941 г., то есть более чем на месяц позже. Вероятно, Р. Батц понял слова Р. Гейдриха о необходимости уничтожения восточного еврейства как призыв к немедленным решительным действиям; в то время как для К. Егера эти слова означали лишь общую установку, и поэтому он решил не торопиться и действовать не на основе призывов, а ожидать конкретных четких недвусмысленных приказов. Р. Гейдрих в оперативном приказе № 2 от 1 июля 1941 г. подчеркнул, что «акции по очистке в первую очередь должны распространяться на большевиков и евреев» ${ }^{64}$. При желании под евреями можно было понимать евреев вообще и соответственно действовать, а можно было сделать вид, что не понятно, о каких евреях идет речь, и ожидать дальнейших, более конкретных, указаний и разъяснений.

Тот факт, что многие «фюреры» команд СД не торопились выполнять «приказ фюрера», можно объяснить также и тем, что они, по словам бывшего «фюрера» оперативной команды 9 Альфреда Фильберта, «были очень поражены, получив такой приказ. Он породил у всех связанных с ним офицеров и рядовых тяжелые душевные конфликты. Поскольку имелось значительное доверие друг к другу, в узком кругу об этом говорили открыто. Но мы пришли к выводу, что отказ выполнять

$\overline{{ }^{64} \text { Klein, Die Einsatzgruppen in der Sowjetunion 1941/42, } 320 .}$ этот приказ повлечет собственный расстрел» ${ }^{65}$. Среди шокированных приказом был и вновь назначенный «фюрером» оперативной команды 8 Эрнст Элерс, на которого этот приказ

[...] подействовал, как удар дубинкой, и я даже не мог понять, как можно было отдать такое распоряжение. Я с ужасом думал, как мне избежсть этой деятельности, и решил просить назначенного на должность шефа моей оперативной группы Небе сменить меня на посту руководителя оперативной команды 8. Небе, не противясь, пошёл навстречу моему желанию и взял меня в штаб своей группы. В связи с этим он мне также сообщил, что руководителем оперативной команды 8 назначен прежний референт штаба его группы, а именно д-р Брадфиш ${ }^{6 .}$

Другой пример разного отношения к приказу об уничтожении евреев: в ходе прочесывания «припятских болот» (южные районы Белоруссии) в августе 1941 г. в полосе конного дивизиона (Г. Ломбард) 1-го кавалерийского полка СС истреблялись все евреи поголовно, в то время как в полосе прочесывания конного дивизиона (Франц Магилл) 2-го кавалерийского полка СС расстреливались только евреи-мужчины, да и то далеко не во всех населенных пунктах. Ф. Магилл, в отличие от Г. Ломбарда, считал, что войска СС не следует привлекать к расстрелам женщин и детей, так как это развращает солдат и подрывает дисциплину.

\section{Периодизация Холокоста в СССР И. Альтмана и ее критика}

Еще одну периодизацию Холокоста в СССР предложил известный российский исследователь Холокоста И. Альтман. Он также выделяет три этапа, причем вехой между первым и вторым этапом является, по его мнению, «Ваннзейская конференция» (январь 1942 г.), а вехой между вторым и третьим этапом - завершение ликвидации гетто и рабочих лагерей на оккупированной советской территории (осень 1943 г. $)^{67}$. Что касается второй вехи, то это - количественные изменения, которые критерием, как мы показали выше, быть не могут. Вехой не может быть, по нашему мнению, и «Ваннзейская конференция», значение которой неправомерно раздуто и преувеличено ${ }^{68}$.

${ }_{65}$ См.: BArch B162/4108, BI. $72-73$ (показания Э. Элерса 17 апреля 1959 г.).

${ }^{66}$ См.: BArch B162/2400, BI. 9-10 (показания бывшего «фюрера» оперативной команды 9 А. Фильберта 11 мая 1959 г.).

${ }^{67}$ Илья Альтман, Жертвы ненависти: Холокост в СССР 1941-1945 гг. (Москва: Фонд «Ковчег», 2002), 233.

${ }^{68}$ Об оценке «Ваннзейской конференции» см.: Christian Gerlach, Sur la conférence de Wannsee (Paris: Éditions Liana Levi, 1999); Mark Roseman, Die Wannsee-Konferenz: Wie die Bürokratie den Holocaust organisierte (Berlin: Propyläen Verlag, 2002); Gedenk- und Bildungsstätte Haus der Wannsee- 
Предыстория конференции такова: 31 июля 1941 г. ${ }^{69}$ Герман Гёринг поручил Рейнхарду Гейдриху разработать план «окончательного решения еврейского вопроса» в Европе с привлечением заинтересованных центральных ведомств нацистской Германии ${ }^{70}$ Во исполнение поручения Г. Гёринга Р. Гейдрих запланировал на 9 декабря 1941 г. проведение совещания с целью выработки «единообразного понимания всеми заинтересованными центральными инстанциями» проблем, возникших в ходе «окончательного решения»", и «создания ясности в принципиальных вопросах». В связи с международными событиями (вступление в войну Японии и США) совещание было перенесено и состоялось 20 января 1942 г. Как видно из протокола совещания $^{12}$, оно не приняло никаких решений (ни стратегических, ни тактических) относительно судьбы еврейского народа и было созвано исключительно для обмена мнениями и согласования позиций тех центральных ведомств нацистской Германии, которые прямо или косвенно были причастны к истреблению евреев ${ }^{73}$. Таким образом, это совещание никак не может быть поворотным пунктом не только в судьбе советских евреев, но и в судьбе евреев Европы в целом. Кстати, на этом совещании Р. Гейдрих выделил два этапа в антиеврейской политике и практике нацистской Германии. Первый этап охватывал период с 30 января 1933 г. до осени 1941 г., когда основным способом решения «еврейского вопроса» была в основном принудительная эмиграция евреев за пределы «Великогерманского рейха» (до 31 октября 1941 г. были вынуждены эмигрировать около 537 тыс. евреев). Второй этап начался осенью 1941 г., когда вместо эмиграции «после соответствующего предварительного одобрения фюрером» стала применяться «эвакуация евреев на Восток». Вначале речь шла только

Konferenz: Die Wannsee-Konferenz und der Völkermord an den europäischen Juden (Berlin, 2006); Norbert Kampe und Peter Klein, hrsg., Die Wannsee-Konferenz am 20 Januar 1942: Dokumente Forschungsstand Kontroversen (Köln: Böhlau, 2013).

${ }^{69}$ У И. Альтмана ошибочно - 2 июля 1941 г. (Альтман, Жертвы ненависти, 233).

${ }^{70}$ Нюрнбергский процесс над главными немецкими военными преступниками: сборник материалов (Москва: Госюриздат, 1966), 3: 247-248

${ }^{71}$ См.: Robert M. W. Kempner, Eichmann und Komplizen (Zürich, Stuttgart, Wien, 1961), 127-128 (письмо Р. Гейдриха унтер-статс-секретарю Лютеру (МИД) от 29 ноября 1941 г.).

${ }^{72}$ CС в действии: документы о преступлениях СС (Москва: Прогресс, 1969), 205-214.

${ }^{73}$ В совещании участвовали представители «министерства оккупированных восточных областей», министерства внутренних дел, министерства юстиции, министерства иностранных дел, «ведомства уполномоченного по четырехлетнему плану», «партийной канцелярии», «имперской канцелярии», «правительства польского генерал-губернаторства», Главного управления СС по вопросам расы и поселений, РСХА. о помещении «имперских евреев» в восточные гетто (Лодзь, Рига, Минск), но уже в середине декабря 1941 г. А. Гитлер принял решение о физическим истреблении европейских евреев: на совещании с Г. Гиммлером 18 декабря 1941 г. А. Гитлер дал ему прямое указание «истреблять евреев как партизан» ${ }^{74}$

Таким образом, можно констатировать, что в Холокосте в СССР был только один качественный скачок. Исходя из этого, в политике и практике истребления советских евреев можно, на наш взгляд, выделить только два этапа. Первый этап - с 22 июня 1941 г. до перехода к поголовному истреблению евреев - и второй этап - с этого момента до полного освобождения советской территории. Правда, в октябре 1944 г. Г. Гиммлер отдал приказ о прекращении физического уничтожения евреев ${ }^{75}$. Это событие также можно считать определенной вехой, положившей начало новому этапу. Однако для СССР приказ уже не имел никакого значения, так как к тому времени освобождение ранее оккупированной советской территории завершилось.

Alexander Kruglov

\section{HOLOCAUST IN OCCUPIED REGIONS OF THE USSR: THE PROBLEM OF PERIODIZATION AND REGIONAL FEATURES}

The article provides a critical overview of the existing variants of the Holocaust periodization in the Former Soviet Union suggested by an Israeli historian and Holocaust researcher Yitzhak Arad and a Russian historian Iliya Altman. Describing periodization, both Arad and Altman rely on quantitative changes and external Holocaust factors, while the author of this article argues that the research-based periodization should rely on qualitative changes and reasoning behind the phenomenon under study (in this case, the Holocaust). Leaning on these principles, the authors infers a conclusion that the Holocaust in the USSR can be divided into two stages only.



${ }^{75}$ Trial of the major war criminals before the International Military Tribunal: Nuremberg 14 November 1945 - 1 October 1946 (Germany: Nuremberg, 1947), 4:360 (показания свидетеля Дитера Висличени (Dieter Wisliceny) на заседании Международного Военного Трибунала 3 января 1946 г.); Нюрнбергский процесс над главными немецкими военными преступниками, 587-588 (заявление Нюрнбергский процесс над главными немецкими военными преступниками, 587-588 (заявление
бывшего штандартенфюрера СС Курта Бехера (Kurt Becher) от 8 марта 1946 г.); Rudolf Höss, Kommandant in Auschwitz: Autobiographische Aufzeichnungen (Stuttgart: Deutsche Verlags-Anstalt, 1958), 160 (письменные показания (ноябрь 1946 г., Краков) бывшего коменданта концлагеря Аушвиц Рудольфа Хёсса).
} 
The first stage started on 22 June 1941 and lasted till the total destruction of the Jews; the second stage stemmed from that very moment and lasted till the complete liberation of the Soviet territory.

Having explored appropriate literature as well as German and Soviet documents (dispatches of German penal institutions, ESC reports), the author states that in different occupied areas of the USSR, the transition to total destruction of the Jews did not happen simultaneously, but at different time - in early July 1941 in Latvia and Belarus (Bialystok region), in midAugust 1941 in Lithuania and in the third decade of August 1941 in Ukraine. In the author's opinion, such time difference was human-generated, and the fact that total destruction of the Jews had started in early July 1941 suggests that the key decision on destroying the Soviet Jews as Bolshevist Jews (the so-called «Führer's Order», i.e. Hitler's) was most likely to have been made before the German invasion of the USSR. The article provides postwar testimonies of a number of SD teams' ex-» Führers», according to which the «Führer's Order» had been announced before the «campaign against Russia» was launched.

Key words: Holocaust in the USSR, periodization of the Holocaust, occupied territory, extermination of Jews, mass shootings.

\section{Олександр Круглов}

\section{ГОЛОКОСТ В ОКУПОВАНИХ РЕГІОНАХ СРСР: ПРОБЛЕМА ПЕРІОДИЗАЦІЇ ТА РЕГІОНАЛЬНІ ОСОБЛИВОСТІ}

У статті критично розглядаються та аналізуються наявні варіанти періодизації Голокосту в СРСР, запропоновані ізраїльським істориком та дослідником Іцхаком Арадом та російським істориком Іллею Альтманом. Обидва історики в основу періодизації кладуть кількісні зміни та зовнішні по відношенню до Голокосту фактори, в той час як, на думку автора цієї статті, наукова періодизація повинна базуватися на якісних змінах та внутрішній логіці розвитку досліджуваного явища. Виходячи з цих принципів, автор доходить висновку, що Голокост в СРСР можна розділити на два етапи. Перший - з 22 червня 1941 р. до початку поголовного знищення євреїв, другий - $з$ цього моменту до повного звільнення радянської території.

На основі вивчення відповідної наукової літератури, німецьких та радянських документів, зокрема донесення німецьких карательних органів, актів НДК (ЧГК), автор констатує, що в різних окупованих регіонах СРСР перехід до поголовного знищення євреїв відбувся не одночасно, а по-різному: в Латвії і в Білорусі (Білостокська область) - на початку липня 1941 р., у Литві в середині серпня 1941 р., в Україні - у третій декаді серпня 1941 р. На думку автора, в основі цієї різномоментності знаходився людський фактор, а сам факт початку поголовного винищення євреїв уже на початку липня 1941 р. говорить про те, що принципове рішення про знищення радянських євреїв як більшовистських (так званий «наказ фюрера») було прийнято, скоріш за все, до нападу Німеччини на СРСР. У статті наводяться післявоєнні свідчення низки колишніх «фюрерів» команд СД про те, що про «наказ фюрера» їм було оголошено ще до початку «кампанії проти Росії».

Ключові слова: Голокост в СРСР, періодизація Голокосту, окупована територія, винищення євреїв, масові розстріли.

\section{Bibliography}

Al'tman, Il'ya. Zhertvy nenavisti: Kholokost v SSSR: 1941-1945 gg. Moskva: Fond «Kovcheg», 2002.

Aly, Götz. «Der 12 Dezember 1941.» Berliner Zeitung 13 (Dezember 1997).

Arad, Yitzhak. Katastrofa evreev na okkupirovannykh territoriyakh Sovetskogo Soyuza (1941-1945). Dnepropetrovsk: Tsentr «Tkuma», ChP «Lira LTD»; Moskva: Tsentr «Kholokost», 2007.

Arad, Yitzhak, red. Unichtozhenie evreev SSSR v gody nemetskoy okkupatsii (1941-1944): sbornik dokumentov i materialov. Ierusalim: Yad VaShem, 1991.

Baade, Fritz, hrsg. Unsere Ehre heißt Treue: Kriegstagebuch des Kommandostabes Reichsführer SS. Tätigkeitsberichte der 1. Und 2. SS-Inf. Brigade, der 1. SS-Kav.-Brigade und von Sonderkommandos der SS. Frankfurtam-Main, Wien, Zürich: Europa-Vlg., 1965.

Baranauskas, Boleslovas ir Eusiejus Rozauskas, red. Masinès žudynès Lietuvoje, 1941-1944: dokumentu rinkinys. Vilnius: Leidykla «Mintis», 1973.

Boll, Bernd. «Aktionen nach Kriegsbrauch. Wehrmacht und 1. SS-Infanteriebrigade 1941.» Zeitschrift für Geschichtswissenschaft 48, no. 9 (2000): 775.

Browning, Christopher. «Hitler and the Euphoria of Victory: The path to the Final Solution.» In The Final Solution: origins and implementation, edited by David Cesarani, 137-147. London, New York: Routledge, 1994. 
Browning, Christopher. Ordinary men: Reserve Police Battalion 101 and Final Solution in Poland. New York: Penguin books, 1992.

«Chomsk.» In The Yad Vashem Encyclopedia of the Ghettos During the Holocaust, edited by Guy Miron, vol. 1: 114. Jerusalem, 2009.

Curilla, Wolfgang. Die deutsche Ordnungspolizei und der Holocaust im Baltikum und in Weißrußland 1941-1944. Paderborn: Schöningh, 2005.

Dean, Martin. «Chomsk.» In Encyclopedia of Camps and Ghettos, 19331945, edited by Geoffrey P. Megargee and Martin Dean, vol. 2: 1341-1342. Bloomington, Indianapolis: Indiana University Press, 2012.

Deko, Oleksandr. Kedoyshim. Povist'-khronika Shepetivs'koho hetto. Kyyiv, 1995.

Dieckmann, Christoph. «Lithuania in summer 1941: the German invasion and the Kaunas pogrom.» In Shared history - divided memory: Jews and others in Soviet-occupied Poland, 1939-1941, edited by Elazar Barkan, Elizabeth A. Cole and Kai Struve, 355-385. Leipzig: Leipziger Universitätsverlag GMBN, 2007.

Dmitrów, Edmund. «Oddzialy operacyjne niemieckiej Policji Bezpieczeństwa i Służby Bezpieczeństwa a początek zagłady Żydow w Łomżyńskiem i na Białostocczyźnie latem 1941 roku.» In Wokół Jedwabnego, pod redakcja Pawło Machcewicz i Krzysztof Persak, t. 1: 323-350. Warszawa: Instytut Pamięci Narodowej, 2002.

Dmitryw, Edmund, Pawel Machcewicz, und Tomasz Szarota. Der Beginn der Vernichtung: zum Mord an den Juden in Jedwabne und Umgebung im Sommer 1941. Osnabrück: Fibre, 2004.

Ezergailis, Andrew. The Holocaust in Latvia 1941-1944: The Missing Center. Riga: Historical Institute of Latvia, in association with the United States Holocaust Memorial Museum, Washington, D.C., 1996

Gedenk- und Bildungsstätte Haus der Wannsee-Konferenz: Die Wannsee-Konferenz und der Völkermord an den europäischen Juden. Berlin, 2006.

Gerlach, Christian. «Die Wannsee-Konferenz, das Schicksal der deutschen Juden und Hitlers politische Grundsatzentscheidung alle Juden Europas zu ermorden.» WerkstattGeschichte 18 (1997): 7-44.

Gerlach, Christian. Krieg Ernährung Völkermord. Deutsche Vernichtungspolitik im Zweiten Weltkrieg. München: Pendo Zürich, 2001.

Gerlach, Christian. Sur la conférence de Wannsee. Paris: Éditions Liana Levi, 1999.
Gerlach, Christian. «The Wannsee Conference, the Fate of German Jews, and Hitler's Decision in Principle to Exterminate All European Jews.» Journal of Modern History (December 1998): 759-812.

Groscurth, Helmuth. Tagebücher eines Abwehroffiziers 1938-1940. Stuttgart: DVA, Deutsche Verlagsanstalt, 1970.

Gross, Jan Tomasz. Neighbors: the destruction of the Jewish community in Jedwabne. Poland, N.J.: Princeton University Press, 2001.

Gross, Jan Tomasz. Wokót «Sasiadyw»: polemiki $i$ wyjasnienia. Sejny: Pogranicze, 2003.

Herbert, Ulrich. «Vernichtungspolitik: Neue Antworten und Fragen zur Geschichte des Holocaust.» In Nationalsozialistische Vernichtungspolitik 1939-1945: Neue Forschungen und Kontroversen, 9-66. Frankfurt-amMain: Fischer, 1998.

Hoppe, Bert und Hildrun Glass, hrsg. Die Verfolgung und Ermordung der europäischen Juden durch das nationalsozialistische Deutschland 1933-1945, bd. 7: 223-225. München: Oldenbourg Wissenschaftsverlag, 2011.

Höss, Rudolf. Kommandant in Auschwitz: Autobiographische Aufzeichnungen. Stuttgart: Deutsche Verlags-Anstalt, 1958.

Kampe, Norbert und Peter Klein, hrsg. Die Wannsee-Konferenz am 20 Januar 1942: Dokumente Forschungsstand Kontroversen. Köln: Böhlau, 2013.

Kay, Alex J. «Transition to Genocide, July 1941: Einsatzkommando 9 and the Annihilation of Soviet Jewry.» In Holocaust and Genocide Studies 27, no. 3 (Winter 2013): 424-425.

Kempner, Robert M.W. Eichmann und Komplizen. Zürich, Stuttgart, Wien, 1961.

«Kholokost v Daugavpilse.» Data obrashcheniya 2 Oktjabrja, 2018. http://www.gorod.lv/novosti/14248/holokost_v_daugavpilse.

Kruglov, Aleksandr. ««Evreyskaya aktsiya» v Kamenets-Podol'skom v kontse avgusta $1941 \mathrm{~g} . \mathrm{v}$ svete nemetskikh dokumentov.» Holokost $i$ suchasnist': naukovyy chasopys, № 1 (2005): 43-48.

Kruglov, Aleksandr. «Pogromy v Vostochnoy Galitsii leta 1941 g.: organizatory, uchastniki, masshtaby i posledstviya.» Problemi istorii Golokostu: naukoviy zhurnal, № 5 (2010): 56-74.

Kruglov, Aleksandr. «Pogromy v Vostochnoy Galitsii letom 1941 g.: organizatory, uchastniki, masshtaby i posledstviya.» V Voyna na unichtozhenie: natsistskaya politika genotsida na territorii Vostochnoy Evropy: materialy mezhdunarodnoy nauchnoy konferentsii, Moskva, 26-28 aprelya 2010, 324341. Moskva: Fond «Istoricheskaya pamyat'», 2010. 
Kruglov, Aleksandr. Poteri evreev Ukrainy v 1941-1944 gg. Khar'kov: Tarbut Laam, 2005.

Kruglov, Alexander, and Geoffrey P. Megargee. «Plunge.» In Encyclopedia of Camps and Ghettos, 1933-1945, edited by Geoffrey P. Megargee and Martin Dean, vol. 2: 1105. Bloomington, Indianapolis: Indiana University Press, 2012.

Kruglov, Alexander, and Martin Dean. «Wilejka.» In Encyclopedia of Camps and Ghettos, 1933-1945, edited by Geoffrey P. Megargee and Martin Dean, vol. 2: 1299-1300. Bloomington, Indianapolis: Indiana University Press, 2012.

«Linkuva.» In Lithuanian Jewry, vol. 4: 306. Tel Aviv: Association of Former Lithuanians in Israel, 1984.

«Linkuva.»In Pinkas Hakehillot Lita: encyclopedia of Jewish Communities, Lithuania, edited by Dov Levin and Yosef Rosin. Jerusalem: Yad Vashem, 1996.

Mallmann, Klaus-Michael. «Der qualitative Sprung im Vernichtungsprozeß: Das Massaker von Kamenez-Podolsk Ende August 1941.» Jahrbuch für Antisemitismusforschung 10 (2001): 239-264.

Margolin, Maksim. Kholokost v Latvii: «Ubit' vsekh evreev'». Moskva: Veche, 2011.

Matthäus, Jürgen. «Operation Barbarossa and the Onset of the Holocaust, June-December 1941.» In The Origins of the Final Solution: The Evolution of the Nazi Jewish Policy, September 1939 - March 1942, aut. Christopher Browning, 244-308. Lincoln: University of Nebraska Press, Jerusalem: Yad Vashem, 2004.

Meler, Meyer. Mesta nashey pamyati: evreyskie obshchiny Latvii, unichtozhennye $v$ Kholokoste. Riga: Rizhskaya evreyskaya obshchina, Muzey «Evrei Latvii», 2010.

Mędykowski, Witold. W cieniu gigantów: pogromy $1941 r$. w byłej sowieckiej strefie okupacyjnej: kontekst historyczny, społeczny i kulturowy. Warszawa: PAN, 2012. 2001.

Niekrasz, Lech Z. Operacja «Jedwabne»: mity i fakty. Wroclaw: Nortom,

Nyurnbergskiy protsess nad glavnymi nemetskimi voennymi prestupnikami: sbornik materialov, t. 3: 247-248. Moskva: Gosyurizdat, 1966.

Ogorreck, Ralf. Die Einsatzgruppen und die «Genesis der Endlösung». Berlin: Metropol-Verl., 1996.
Pohl, Dieter. «Anti-Jewish pogroms in Western Ukraine: a research agenda.» In Shared history - divided memory: Jews and others in Soviet-occupied Poland, 1939-1941, edited by Elazar Barkan, Elizabeth A. Cole and Kai Struve, 305-313. Leipzig: Leipziger Universitätsverlag GMBN, 2007.

Pohl, Dieter. «Schauplatz Ukraine: Der Massenmord an der Juden im Militärverwaltungsgebiet und im Reichskommissariat 1941-1943.» In Ausbeutung, Vernichtung, Öffentlichkeit. Neue Studien zur nationalsozialistischen Lagerpolitik, herausgegeben von Norbert Frei, Sybille Steinbacher und Bernd Wagner, 135-174. München: De Gruyter Saur, 2000.

Pohl, Dieter. «The Murder of Ukraine's Jews under German Military Administration and in the Reich Commissariat Ukraine.» In The Shoah in Ukraine: History, Testimony, Memorialization, edited by Ray Brandon and Wendy Lower, 23-76. Bloomington: Indiana University Press, 2008.

Poliak, Aaron Leib. Hurban Motele (The Destruction of Motele). Edited by Dr. Dov Yarden. Jerusalem: Council of Motele Immigrants, 1956.

Rochko, Iosif. «Ilukste.»V Kholokost na territorii SSSR: entsiklopediya, red. Il'ya Al'tman. Moskva: ROSSPEN, 2009.

Roseman, Mark. Die Wannsee-Konferenz: Wie die Bürokratie den Holocaust organisierte. Berlin: Propyläen Verlag, 2002.

Rzepliński, Andrzej. «Ten jest z ojczyzny mojej? Sprawy karne oskarżonych o wymordowanie Żydów w Jedwabnem w świetle zasady rzetelnego procesu.» In Wokół Jedwabnego, pod redakcją Pawło Machcewicz i Krzysztof Persak, t. 1: 353-459. Warszawa: Instytut Pamięci Narodowej, 2002.

«Saukenai.» In The Holocaust in 21 Lithuanian Towns, compil. and trans. Joe Woolf. Data obrashcheniya 18 Oktjabrja, 2018. http://www.jewishgen. org/Yizkor/lithuania3/lithuania3.html.

Smilovitskiy, Leonid. Katastrofa evreev v Belorussii, 1941-1944 gg. Tel'Aviv: Biblioteka Matveya Chernova, 2000.

Smirin, Grigoriy. «Subate.»V Kholokost na territorii SSSR: entsiklopediya, red. Il'ya Al'tman. Moskva: ROSSPEN, 2009.

Smirin, Grigoriy, i Meyer Meler. «Borovka v Latvii.» Lekhaim: ezhemesyachnyy literaturno-publitsisticheskiy zhurnal, № 10 (114) (2001): 18-21.

SS v deystvii: dokumenty o prestupleniyakh SS. Moskva: Progress, 1969.

Struve, Kai. «Rites of Violence? The Pogroms of Summer 1941.» Polin: Studies in Polish Jewry 24 (2012): 257-274.

Tomašūns, Andris. «Jelgavā nogalinātie ebreji: padomju un nacistu dati.» In Holokausts Latvijā: starptautiskās konferences materiāli 2004 gada 3-4 
jūnijs, Rìga, un 2004-2005 gada pētījumi par holokaustu Latvijāa, 162-183. Rīga: Latvijas vēstures institūta apgāds, 2006.

Trial of the major war criminals before the International Military Tribunal: Nuremberg 14 November 1945-1 October 1946, vol. 4: 360. Germany: Nuremberg, 1947.

Trials of war criminals before the Nuernberg Military Tribunals under Control Council Law no. 10, vol. 4: 519. Washington, 1950.

«Urteil LG Berlin, 3 PKs 1/62, v. 22.6.1962 gg. Filbert u.a.»Justiz und NS-Verbrechen: Sammlung deutscher Strafurteile wegen nationalsozialistischer Tötungsverbrechen 1945-1966, bd. 18: 620. Amsterdam, 1968.

«Viesite.»V Rossiyskaya Evreyskaya Entsiklopediya, t. 4: 239. Moskva, 2000.

Vỉksne, Rudīte. «Ebreju iznīcināšana Aucē 1941 gada jūlijā.» In Holokausta izpētes jautājumi Latvijā: starptautiskā semināra referāti 2001 gada 29 novembris, Riga, un 2001-2002 gada pêtijumi par holokaustu Latvijā, 101126. Rīga: Latvijas vēstures institūta apgāds, 2003.

Witte, Peter, Michael Wildt, und Martina Voigt. Der Dienstkalender Heinrich Himmlers 1941/42. Hamburg: Hans Christians Verlag, 1999.

Żbikowski, Andrzej. «Lokalne pogromy żydow w czerwcu i lipcu 1941 roku na wschodnich rubieżach II Rzeczypospolitej.» Biuletyn Żydowskiego Instytutu Historycznego, no. 2-3 (1992).

Żbikowski, Andrzej. «Pogroms in northeastern Poland: spontaneous reactions and German instigations.» In Shared history - divided memory: Jews and others in Soviet-occupied Poland, 1939-1941, edited by Elazar Barkan, Elizabeth A. Cole and Kai Struve, 315-354. Leipzig: Leipziger Universitätsverlag GMBN, 2007.

Żbikowski, Andrzej. «Pogromy i mordy ludności żydowskiej w Łomżyńskiem i na Białostocczyźnie latem 1941 roku w świetle relacji ocalałych Żydow i dokumentow sądowych.» In Wokół Jedwabnego, pod redakcją Pawło Machcewicz i Krzysztof Persak, t. 1: 159-271. Warszawa: Instytut Pamięci Narodowej, 2002.

\section{Archives}

Arkhiv prokuratury Regensburga.

Bundesarchiv (BArch) B162/278, 435, 437, 1231, 2400, 2503, 3300, 3769, 4108, 5658, 5863, 9336-9338, 14317, 17913, 19407, 20212, 20216; RH20-6/111.

Bundesarchiv-Militärarchiv, RS3-8/36, 4/441.
Gosudarstvennyi arkhiv Rossiiskoi Federatsii (GARF). F. 7021, op. 84, d. 13; op. 87, d. 4; op. 93, d. 130, 134, 2410, 2415; op. 94, d. 436.

National Archives and Record Administration (NARA). M 895, roll 14,15 .

Rossiyskiy gosudarstvennyy voennyy arkhiv (RGVA). F. 500, op. 1, d. 25. 